Jenny Hellgren is a qualified secondary-school teacher in Chemistry and Biology with a PhD in Pedagogical Work and a PhD in Plant Physiology. Her primary research interests are: student motivation for learning science and mathematics in secondary school with a focus on the importance of authentic learning experiences for school science; and teacher professional development in working with socio-scientific issues and supporting students' development of competences such as argumentation and critical thinking.

JENNY M. HELLGREN

Department of Science and Mathematics Education, Umeå University, Sweden

jenny.s.hellgren@umu.se

\title{
Authentic science in the classroom students' perceptions of their experiences
}

\begin{abstract}
The purpose of this study is to characterize how students experience taking part in authentic research, specifically through the Medicine Hunt, a project designed to increase motivation for science and understanding of research in the Swedish secondary school. The study also investigates potential differences in students' experiences related to context, in terms of participating in the Medicine Hunt in different classrooms. Twenty-four students from three Swedish lower-secondary schools participating in the Medicine Hunt were interviewed. The main result is that students' experiences were positive and related to science. Their focus is to a large extent on authentic science, and covers many of the aspects the Medicine Hunt is aiming to introduce in school, like the hands-on and inquiry-based ways of working and the opportunity to do what scientists do. Students' answers are also to a high degree connected to the science content and to learning science. Few differences in students' experiences related to the different classrooms were found.
\end{abstract}

\section{INTRODUCTION}

School science is often accused of being fact-based, difficult and of not using its full potential for developing student creativity, exploration and critical thinking (e.g. Lyons, 2006; Sjøberg \& Schreiner, 2010). School science curricula, e.g. the Swedish National Curriculum (The Swedish National Agency for Education, 2011), however, highlight the importance of students developing skills in problem solving, critical thinking and exploration as well as creativity, confidence and independence. Thus, although school science curricula acknowledge the science subjects' potential for supporting development in these ways, reports show that many students are not sufficiently motivated in science (OECD, 2008; Sjøberg \& Schreiner, 2010). One potential way to address this situation is to provide more stimulating science learning environments that better balance learning facts and being creative, and repeating and reasoning. These features are important to support in the science classroom because they help students to reach science curricula goals and have the potential to motivate students (OECD, 2008; Ryan \& Deci, 2000).

Involving school students in authentic research projects offers a potential way to introduce more creativity, reasoning and inquiry in the science classroom. Therefore, the Nobel Museum in Stockholm, 
Sweden, set up a student-teacher-scientist partnership (STSP) programme called Help a Scientist to involve students in authentic research projects as a part of their school science experience. The Medicine Hunt, that is the focus of this paper, was one element of the Help a Scientist programme. The Medicine Hunt was organised as a six-month STSP in which students worked with an authentic research question with their teacher in their school and communicated with scientists through webbased platforms. The focus for the Medicine Hunt was to find new secondary metabolites from actionomycetes. These are a group of bacteria known to produce secondary metabolites with antibiotic effects that are considered by professional scientists to be worth investigating as potential important components in the development of future antibiotics.

The project was implemented in 18 lower secondary school classes (student age 13-14) across Sweden. In the project, the students were active participants together with University researchers in many of the steps of an authentic research project. The research reported here sheds light on how students experience taking part in authentic research; especially what features of the STSP the students highlight and appreciate.

\section{BACKGROUND}

\section{Students' experiences of school science}

How students experience science in general, and school science in particular, may depend on their views of school science, their previous experiences of science and the way they have been introduced to science. Zacharia and Calabrese Barton (2004) described three major school science cultures: Traditional School Science (TSS), Progressive School Science (PSS) and Critical School Science (CSS). These differ in the way they view knowledge and the way they view the relationship between students, teachers and science (Zacharia \& Calabrese Barton, 2004). TSS is based on a positivist worldview and presents knowledge as something objective to retrieve from textbooks and discover through lectures and experimental procedures. The goal is to memorize scientific knowledge produced by others.

PSS, in contrast, is based in the constructivist tradition, presenting knowledge as grounded in what scientists produce as well as in ideas, discursive practices and habits of mind. In comparison to TSS, where there are right and wrong answers, in PSS concepts can be described in many different ways. Thus, rather than the goals of science being to memorize facts, students are expected to develop knowledge, understanding and habits for informed and active citizenship in their everyday lives.

Unlike TSS and PSS, CSS is based on a subjective world-view and critical perspectives, and it sees science as a social activity involving human values and societal challenges with few right answers and many perspectives. Critically, CSS students are considered to be producers as well as users of science as they develop into informed and active citizens. It is important, however, to remember, that as Zacharia and Calabrese Barton (2004) highlighted, these three school science cultures are not exclusive; on the contrary, there is often an overlap between them.

Of note is that students have been reported as describing school science as decontextualized, teachercentred and unnecessary difficult (e.g. Lyons, 2006; Osborne \& Dillon, 2008), and many of the reported descriptions align with TSS. For example, Lyons' synthesised studies from Sweden, as well as England and Australia, and reported that when students express their experiences of school science in their own words there are three re-occurring themes regardless of country: decontextualized, teacher-centred and unnecessarily difficult. Lyons concluded that:

students in different educational and national contexts were not only experiencing very similar high school science classes, but identifying similar problems and responding in similar ways (p. 592).

These re-occurring themes indicate that, from students' point of view, addressing these issues has clear potential to enrich school science. 
To understand how to get students to become more interested in science other researchers have explicitly focused on what motivates students in science (e.g. Potvin \& Hasni, 2014), and here, many of the factors highlighted align with PSS and CSS. For example, when using open approaches to ask students which classroom factors motivate them, aspects of collaborative, authentic and hands-on learning activities have been brought up by students as important (Bryan, Glynn \& Kittleson, 2011; Velayutham \& Aldridge, 2013). Further, Potvin \& Hasni (2014) reviewed literature on student motivation, interest and attitudes towards science. They reported positive links between motivation, attitudes and interest and enthusiastic and encouraging teachers, collaborative work, meaningful learning linked to daily life, hands-on and inquiry-based work, and learning environments that encourage independent thinking. Further, they found that key aspects in successful science interventions appeared to be inquiry- or problem-based learning, hands on-learning, collaborative work, contextualisation and contact with role models. Thus, based on the literature, it is apparent that many features of the Medicine Hunt have the potential to motivate students in their science learning.

In sum, the Medicine Hunt aimed to encourage PSS, along with some aspects of CSS, and to move the learning culture focus from learning facts to developing knowledge that is useful in everyday life. Further, the Medicine Hunt aimed to do this within the frame of the Swedish science curriculum, rather than as an optional extra-curricula learning experience that would probably not be experienced by as broad a range of school students. Experiences of the school-based Medicine Hunt were likely to be different from those described in Lyons (2006), and the Medicine Hunt had the potential to give students an extended view of school science.

\section{Authentic science in school}

Authentic science can be defined as activities that immerse participants in real scientific issues and problems. It can be introduced in school in different ways, for example through excursions to universities, laboratories, museums or science centres, that are usually isolated experiences, or through inclusion as an aspect of teachers' ways of working with science teaching. Hence, for an activity to be considered as authentic science in the archived literature has not required participation in authentic contemporary science research in the way of the Medicine Hunt.

Braund and Reiss (2006) argued that authentic school science-meaning an experience in school that has authenticity-should

provide experiences that are more in line with the sorts of activities that scientists and technologists do in the real world of science and that such experiences should include student-directed tasks and more open-ended enquiries (p. 1375-1376).

Working from this definition, the Medicine Hunt was an authentic science experience in school because it provided school students an experience of an activity that scientists were doing in the real world through an authentic research problem (the hunt for new substances that can serve as antibiotics in the future) that was also a real scientific issue for society, namely increased resistance to antibiotics. Further, the Medicine Hunt provided the students with experiences of student-directed tasks and open-ended inquiry through a hands-on and inquiry-based approach to a problem with no pre-determined answer, and through collaboration with scientists working on the same problem.

Projects in which teachers and students work from their classrooms and collaborate with scientists in authentic research projects are today in the literature referred to as student-teacher-scientist partnerships (STSPs; e.g. Houseal, Abd-El-Khalick \& Destefano, 2014; Wormstead, Becker \& Congalton, 2002), but have previously been referred to as student-scientist partnerships (SSPs; e.g. Lawless \& Rock, 1998; Moss, Abrams \& Kull, 1998; Sadler, Burgin, McKinney \& Ponjuan, 2010). In this paper "STSPs" will be used to include the role of the teacher in the partnership. In STSPs, students are given possibilities to gain insight in and practical experience of many of the steps of the scientific procedure-planning, data collection, data analysis and reporting of results. Thus, participation in these projects gives students opportunities to experience core aspects of authentic research as performed by professional scientists. 
However, based on the few research articles examining STSPs published in the scientific literature, one can draw the conclusion that results of these projects have been mixed. For example, Houseal, Abd-El-Khalick and Destefano (2014) reported that students in their intervention-group (participating in the STSP) gained better content knowledge than a comparison-group. Whereas, Moss, Abrams and Kull (1998) found that students' conceptual understanding of scientific research rarely changed over the year the S[T]SP they followed, and that students gained little experience of communicating science.

STSPs have also been shown to lead to positive affective outcomes including getting students more excited about science (Fougere, 1998), giving students feelings of pride and usefulness as active partners in collaboration (Means, 1998) and increasing student interest (Wurstner, Herr, Andrews \& Alley, 2005). This affective dimension was what the Medicine Hunt primarily wanted to target.

\section{Overview, purpose and research questions}

The purpose of this study is to characterize how students' experience taking part in authentic science through the Medicine Hunt, a project that aimed to increase motivation for science and understanding of scientific research in Swedish secondary school. In particular, the study asks whether the students' experience and acknowledge the science content in the STSP. The study also considers potential differences in students' experiences related to the students' participation in different Medicine Hunt classroom contexts.

This study understands learning as a social collective process and the Medicine Hunt as a platform for students to be legitimate peripheral participants (see Lave \& Wenger, 1991) in a scientists' community of practice. With this starting point, the study reported in this paper choose to focus on students' experiences of the Medicine Hunt as described in their own words, analysed using an open, explorative approach.

The results will contribute to earlier reported mixed outcomes from STSPs in schools (e.g. Fougere, 1998; Houseal, Abd-El-Khalick \& Destefano, 2014; Means, 1998; Moss, Abrams \& Kull, 1998; Wurstner, Herr, Andrews \& Alley, 2005) since results from these studies raise questions about the efficiency of STSPs (Sadler, Burgin, McKinney \& Ponjuan, 2010) and how they contribute to school science. A design including three classrooms was adopted to enable us to characterise students' experiences as well as evaluate if they are different in the various classrooms. The qualitative analysis is based on positive experiences since almost no neutral or negative experiences were reported by students. The questions addressed in the study are thus:

1) What features of the STSP do students experience positively?

2) To what extent do students' experiences focus on authentic science, general science and nonscience?

3) What differences are evident in how students perceive the project between classes?

\section{THE INTERVENTION}

Help a Scientist is a six-year programme coordinated by the Nobel Museum in Stockholm, Sweden. The programme aims to increase secondary-school students' interest in science and understanding of research by introducing authentic science into school via various projects. In 2011 the project, the Medicine Hunt, was carried out collaboratively between the Nobel Museum and Laboratories for Chemical Biology Umeå (LCBU). Teachers could express an interest to the Nobel Museum of their class' interest to participate; 18 classes from different parts of Sweden were selected. In total, 388 students participated.

In the classrooms, the science teachers introduced the Medicine Hunt to their students. The students worked with the project in a series of lessons that included collecting soil samples in a local environment of their choice, isolating bacteria and finally characterizing and identifying different bacteria. 
Parallel work with students' soil samples took place in the research laboratory, and students communicated with scientists via a blog, a Facebook-group and a web-based report-form. Scientists also visited some of the classrooms. The last part of the project that included identification of metabolites was for practical and safety reasons only done by the scientists. For the students, the project ended with a poster-competition where all groups presented their findings as scientific posters. Through those activities, students have the potential to gain insight in and practical experience of many of the steps of the scientific procedure-planning, data collection, data analysis and reporting of results. This gave students the opportunity to experience core aspects of authentic research as done by professional scientists.

\section{METHODS}

\section{Overview}

This paper draws on data from an interview study with 24 students (15 girls and 9 boys) from three classes participating in the Medicine Hunt. The students were interviewed after the final laboratory lesson of the Medicine Hunt, with interview questions about their experiences of, first, participating in the project in general and, second, about the lesson they just had. The reason to include both levels was to get an overview of students' experiences of the STSP as a whole at the same time as giving students the possibility to reflect about a lesson and the specific activities immediately afterwards. The reason to include and analyse interviews was to gain insight in the students' own experiences of the STSP as expressed in their own words. This was considered the good way to understand how students' perceive being participants in a partnership with scientists. In order to find themes within the student answers, the verbatim transcribed data was analysed with thematic content analysis (Neuendorf, 2001), and to analyse how frequent the themes occurred in the answers, frequencies were analysed and groups were compared with Fishers exact test (McDonald, 2009).

\section{Participants and procedure}

Participants for this interview study were selected in a two-step procedure. First, three classes were selected from the 18 classes that took part in the Medicine Hunt. This selection was done based on i) schools' geographical location ii) presence of students with both high and low motivation for science in the class, and iii) the teachers welcoming a visit from researchers. Second, students from the classes were asked to participate in the interview-study based on their scores on a motivation questionnaire (a procedure described in detail by Hellgren \& Lindberg, 2017) to ensure variation in the interviewees as both "motivated" and "unmotivated" students could be identified and included in the study. The assumption was that this gives better possibilities for a range of different experiences than would be possible if students were asked to volunteer. All participants were enrolled in grade 7 when the Medicine Hunt was introduced, and in grade 8 at the time for the interviews. In the Swedish school system, this corresponds to the age 13-14 years.

The visit to the schools were planned in collaboration with the teachers. A week before the lesson, the teachers were contacted and asked to inform the classes about the visit and to ask the selected students to participate in the study. The selected students agreed to be interviewed. Teachers, students and their parents were informed about the study and their right to withdraw from it. The parents signed a consent form, and all of the students consented to taking part in the study.

The interviews were conducted after the final laboratory lesson in the project. The classroom activity that had just taken place (in the interviews referred to as "the lesson you just had") was a group task where students worked with identifying bacterial colonies on agar plates. The task was to select colonies of importance and describe them in terms of colour, shape and appearance and to report the groups' findings to the scientists via a webpage. The teachers planned the specific lesson based on instructions from the scientists, but the instructions allowed the teachers to adapt details to their particular classroom situation. This freedom in planning detail therefore allowed for differences between the teachers and classrooms. 
After the lesson, students were interviewed individually in rooms near the classroom. Three researchers interviewed students after the lesson so that all students could be interviewed as soon after the lesson as possible. The interview protocol was semi-structured and all interviews were recorded.

The interview protocol consisted of 14 items, some addressing student motivation and some student experiences. As this study focuses on student experience, items that address the experience of the lesson and of the Medicine Hunt were selected for analysis. These items were: What was it like to work with the task you were given this lesson? Was it fun or boring to work with the task? Why? What did you think about working with Help a Scientist-project? Why?

\section{Data analysis}

The interviews were transcribed, and data analysis was based on students' answers to the interviewitems specified in the instruments section.

\section{Creating the analytical framework by content analysis of student answers}

First, positive, neutral and negative markers for student experiences were identified. Examples of such markers were "fun" and "exciting" (positive), "neither or" (neutral) and "not much fun" (negative). Second, reasons for the positive experiences linked to the markers were identified and extracted. Few clear reasons were given by the students for the neutral and negative markers, and therefore, the neutral and negative reasons were counted and reported, but not analysed further. Third, categories were created through an iterative process of coding. The reasons were sorted into groups of similar reasons for positive experiences, and each group was given a label based on its core important aspects (a process influenced by concepts presented in the background). From this, descriptions that fitted as many of the reasons as possible were written for each category label. This process was repeated until eight groups that could not be further collapsed remained. Towards the end of this iterative process, the categories and the iterative route to the generation were discussed and the categories further developed in a research seminar attended by 10 academics working in science education. By presenting, discussing and working with the categories, the validity and reliability of the categories was strengthened. Through this iterative procedure, the eight categories of reasons for students' positive experiences that were identified, see Table 1, are: do something hands-on, do something inquirybased, do things scientists do, get continuity by following and seeing results of a longer project, do something different, feelings of competence in science, be selected for something special and finally, participate in competition.

\section{Step 1: Features of the STSP the students experience positively}

To answer RQ 1, "what features of the STSP do students experience positively?", frequencies of students' answers in the different categories were calculated. For example, if a student answered: "it was fun to look at the bacteria in microscopes and exciting to see what there was in the soil sample we had collected, we had no idea what it would show", this answer was categorised as 1 (do something hands-on), 2 (do something inquiry based) and 4 (to get continuity). If more than one reason from a student fell in the same category it was still only counted once since the aim was to see the how many students acknowledged each type of experience. This step generated a matrix with 24 students and eight categories for project- and lesson data respectively (see Appendices 1 and 2). Results from the analysis of frequencies are shown in Figure 1.

\section{Step 2: Authentic science, general science and non-science in students' answers}

To overview the science-content in students' answers, the categories achieved in Table 1 were grouped into three groups based on how they related to science. The first group includes aspects of science the Medicine Hunt was aiming to highlight, referred to as "Authentic science" (Category 1-4 in Table 1). The second group includes science-related aspects that are general to science and not specific to the Medicine Hunt. These are referred to as "General science" (Category 5-6 in Table 1). The third group includes aspects that are non-specific or unrelated to science. These are referred to as "Non-science" 
Table 1. Categories of the aspects in the learning situation students refer their positive experiences to, with descriptions of, and examples from across the sample, for each category.

\begin{tabular}{|c|c|}
\hline $\begin{array}{l}\text { During the } \\
\text { project/lesson it } \\
\text { was positive to... }\end{array}$ & $\begin{array}{l}\text { Description and examples from across the student sample to illustrate each } \\
\text { category }\end{array}$ \\
\hline $\begin{array}{l}\text { 1....do something } \\
\text { hands-on }\end{array}$ & $\begin{array}{l}\text { Hands-on activities are defined as activities when students are active and work } \\
\text { practically. This category includes statements that directly refer to hands-on } \\
\text { activities. It also includes statements about the importance of doing hands-on } \\
\text { activities. } \\
\text { Examples: } \\
\text { we did work with bacteria and look in microscopes } \\
\text { you learn better compared to reading it in a book }\end{array}$ \\
\hline $\begin{array}{l}\text { o something } \\
\text { y-based }\end{array}$ & $\begin{array}{l}\text { Inquiry-based activities are defined as students referring to open-ended problems, } \\
\text { taking own responsibility, or exploring something unknown. } \\
\text { Example: } \\
\text { see what happened to the soil samples, they all looked different, we wondered what } \\
\text { they were }\end{array}$ \\
\hline $\begin{array}{l}\text { 3. ...do things } \\
\text { scientists do }\end{array}$ & $\begin{array}{l}\text { The category do things scientists do includes activities that offer students possibilities } \\
\text { to try or better understand science beyond the school science they have already met. } \\
\text { Activities or methods that students have met earlier in school science (for example } \\
\text { look in microscopes) are not included. } \\
\text { In students' answers, do things scientists do is both when students refer directly to } \\
\text { authentic activities not normally occurring in school science (like make scientific } \\
\text { posters or look at bacteria on agar plates), and when students refer to real-world } \\
\text { outcomes (like see if it leads to an important finding). } \\
\text { Examples: } \\
\text { make scientific posters } \\
\text { see if it [the work] leads to an important finding [useful in society] }\end{array}$ \\
\hline $\begin{array}{l}\text { 4. ...get } \\
\text { continuity; follow, } \\
\text { or see results of, a } \\
\text { longer project }\end{array}$ & $\begin{array}{l}\text { Students' answers in this category include continuity by either referring directly to } \\
\text { the sequence of lessons or to continuity by mentioning many aspects and their link to } \\
\text { each other. Answers in this category also include references back to previous work in } \\
\text { connection to results (like see what happened with the samples). } \\
\text { Examples: } \\
\text { to dig and bring it out and see what it became } \\
\text { see what we had collected }\end{array}$ \\
\hline $\begin{array}{l}\text { 5. ...do something } \\
\text { different; get } \\
\text { variation in } \\
\text { science content }\end{array}$ & $\begin{array}{l}\text { Students' answers in this category involve different ways the Medicine Hunt } \\
\text { introduces new things that add variation to science lessons and/or school science. The } \\
\text { answers are often in relation to experiences of what we usually do, but also include } \\
\text { that the Medicine Hunt brought in many new and different things. } \\
\text { Examples: } \\
\text { it was different to what we normally do in science lessons } \\
\text { we got to do many different things }\end{array}$ \\
\hline
\end{tabular}




\begin{tabular}{|c|c|}
\hline $\begin{array}{l}\text { 6. ...ffeelings of } \\
\text { competence in } \\
\text { science }\end{array}$ & $\begin{array}{l}\text { The category includes aspects related to learning, knowing and/or understanding } \\
\text { science better by participating in the project. The aspects can be unspecified (for } \\
\text { example we do learn an awful lot) in a context where it clearly refers to science or } \\
\text { refer to specific content (for example I think I learnt a bit about bacteria). } \\
\text { Examples: } \\
\text { we do learn an awful lot [from participating in the project]! } \\
\text { I think I learnt a bit about bacteria }\end{array}$ \\
\hline $\begin{array}{l}\text { 7. ...be selected } \\
\text { for something } \\
\text { special }\end{array}$ & $\begin{array}{l}\text { The project is something in which not all students in lower secondary school could } \\
\text { participate. This category includes student comments that focus on being selected to } \\
\text { do something special. It also includes the effects of something special happening } \\
\text { such as being contacted by local media. } \\
\text { Example: } \\
\text { it was only a few classes, it felt special }\end{array}$ \\
\hline $\begin{array}{l}\text { 8. ...participate in } \\
\text { competition }\end{array}$ & $\begin{array}{l}\text { The project included a poster competition and the possibility of winning prices. This } \\
\text { category includes outcomes of the project in terms of competition and winning. It } \\
\text { also includes students' comments about competition with peers during the project. } \\
\text { Examples: } \\
\text { I hope we will win } \\
\text { then it is like a competition, who gets the ugliest bacteria, who found the best place to } \\
\text { dig }\end{array}$ \\
\hline $\begin{array}{l}\text { 9. (fits no } \\
\text { category) }\end{array}$ & $\begin{array}{l}\text { Some statements do not fit any category. Reasons for this are that they } \\
\text { a) contain no positive marker and are defined as negative or neutral } \\
\text { or } \\
\text { b) are not specific enough } \\
\text { Examples: } \\
\text { making posters has been difficult because computers were bad } \\
\text { everything has been good, I cannot say something specific }\end{array}$ \\
\hline
\end{tabular}

(Category 7-8 in Table 1). The number of students with reasons categorised in each category-group was counted. The results are presented in Table 2 and provides the answer to RQ 2: "To what extent do students' experiences focus on authentic science, general science and non-science?”

Step 3: Comparing students' experiences between classes

In order to compare student experiences between classes, the matrices in Appendices 1 and 2 were arranged class-wise. After this, the number of students per class and category was summarised to see potential differences in how students experience the Medicine Hunt based on class, data are shown in Table 3. Statistical significance of differences between classes for each category was evaluated using Fishers exact test. This test is used on small group sizes and categorical data, therefore it is suitable for comparing the outcomes between classes. This analysis provides the answer to RQ 3: "what differences are evident in how students perceive the project between classes".

\section{RESULTS}

Students were positive about both the project and the lesson. Regarding the project, 21 responses were classified as positive, three as neutral and none as negative, and regarding the lesson, 22 responses were classified as positive, one as neutral and one as negative. Few clear reasons were given 
for the neutral and negative experiences, and therefore, further analysis focused on only positive markers and reasons. The results section has three parts; each corresponds to one research question and the corresponding step in the data analysis.

\section{Features of the STSP that students experience positively}

The reasons students gave for their positive experiences were classified according to the framework presented in Table 1, and an overview of the number of students who gave reasons falling in each category for experience of project (a) and lesson (b) is shown in Figure 1.

a)

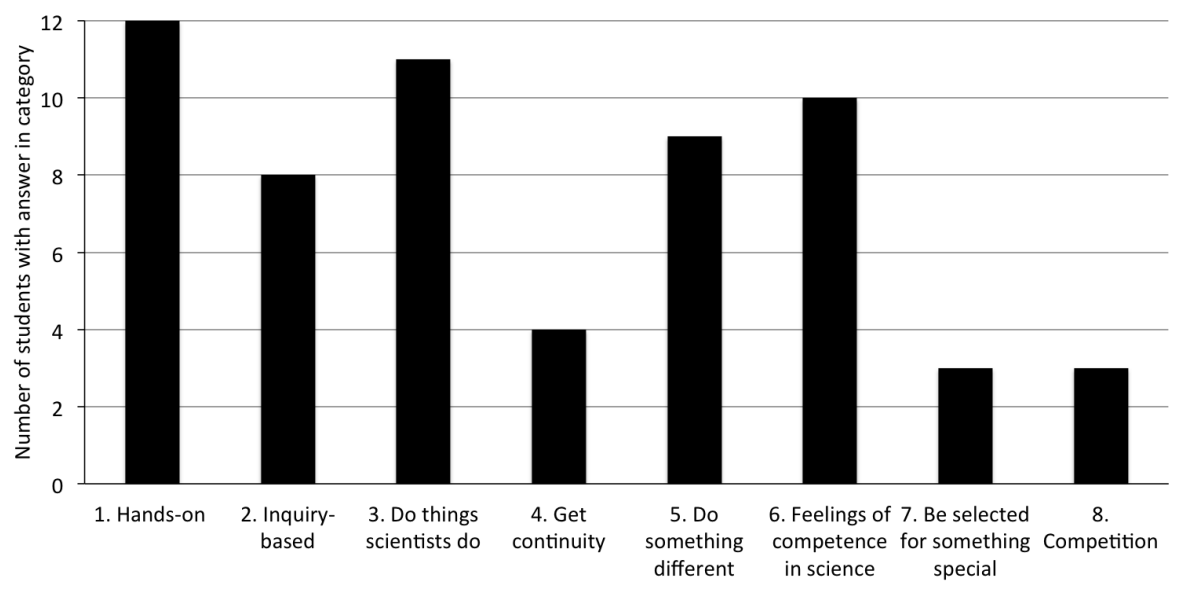

b)

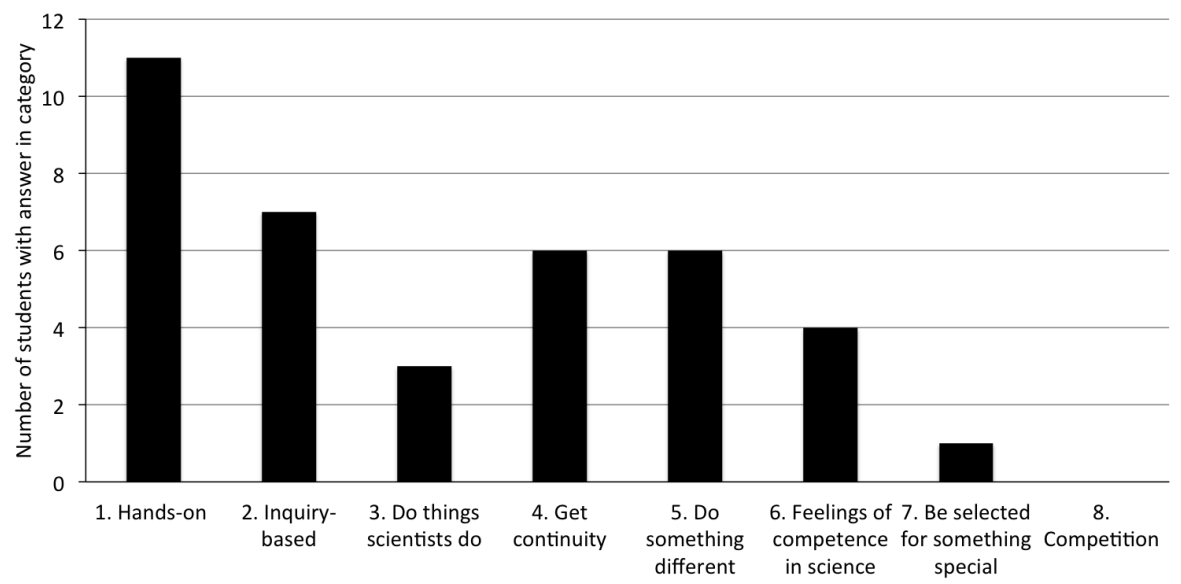

Figure 1. Students' perceptions of their experiences. Each diagram shows the number of students with answers categorised in each category 1-8. a) Shows students experiences of the project and b) shows students experiences of the lesson. A student answer can be categorised in more than one category. 
When discussing the project, the students mostly brought up reasons categorised as: C1: appreciating the hands-on activity (12 reasons); C2: appreciating the inquiry-based activity (8 reasons); $\mathrm{C}_{3}$ : the possibility to do things scientists do (11 reasons); $\mathrm{C}_{5}$ : the different activities the project brought into their school science (9 reasons); and C6: the feelings of competence to learn, know or understand science (10 reasons), see Figure 1a. When discussing the lesson, students mostly brought up reasons categorised as $\mathrm{C} 1$ : the hands-on activity (11 reasons), see Figure $1 \mathrm{~b}$.

\section{Authentic science, general science and non-science in students' answers}

Table 2 shows the number of students (of the total 24) with reasons categorised in each categorygroup for the project and the lesson. In sum, the majority of students attributed their positive experiences to features the Medicine Hunt was aiming to introduce and support and that are common in authentic science. Many of the students also attributed their positive experiences to general, but science-related aspects. Only seven students attributed positive experiences to non-science aspects, and five of those students who did so combined the non-science aspects with science and/or authentic science aspects (see Appendices 1 \& 2).

Table 2. Number of students with answers categorised as Authentic science (Category 1-4), General to science (Category 5-6) and Non-science (Category 7-8). Answers referring to project and lesson are shown separately

\begin{tabular}{|l|c|c|c|}
\hline & Authentic science & Science & Non science \\
\hline Project & 18 & 14 & 6 \\
\hline Lesson & 16 & 10 & 1 \\
\hline
\end{tabular}

\section{Comparing student experiences between classes}

Students' experiences of the Medicine Hunt were similar between classes (see Table 3), both in terms of reasons for enjoying participation in the lesson and the project, and for most categories. Using Fishers exact test, only two of the eight categories were found to be significantly different between classes. Students in Class A said things assigned to Category 1 (they enjoyed doing something handson during the lesson) to a significantly greater extent than students in the other classes $(\mathrm{p}=0,033)$. Further, students in Class C said things assigned to Category 3 (they appreciated doing things scientists do) more $(\mathrm{p}=0,023)$ frequently than students in the other classes, and students in Class B significantly less $(\mathrm{p}=\mathrm{0}, \mathrm{O} 34)$, than students in the other classes. No other statistically significant differences were found between classes.

Table 3. Number of students with answers in each category from class A, B and C respectively. Lesson and project experiences are shown separately. The columns represent the categories from table one.

*significant difference $p<0,05$ with Fishers exact test.

\begin{tabular}{|c|c|c|c|c|c|c|c|c|c|c|}
\hline & & & \multicolumn{8}{|c|}{ Category number } \\
\hline & Class & Student $\mathbf{N}$ & 1 & 2 & 3 & 4 & 5 & 6 & 7 & 8 \\
\hline \multirow{3}{*}{ 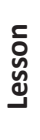 } & A & 9 & $7 *$ & 1 & 2 & 2 & 4 & 0 & 0 & 0 \\
\hline & B & 8 & 3 & 4 & 0 & 2 & 1 & 3 & 0 & 0 \\
\hline & C & 7 & 1 & 2 & 1 & 2 & 1 & 1 & 1 & 0 \\
\hline \multirow{3}{*}{ 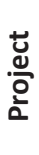 } & A & 9 & 4 & 2 & 4 & 1 & 3 & 3 & 0 & 2 \\
\hline & B & 8 & 4 & 2 & $1^{*}$ & 1 & 4 & 3 & 1 & 1 \\
\hline & $\mathrm{C}$ & 7 & 4 & 4 & $6 *$ & 2 & 2 & 4 & 2 & 0 \\
\hline
\end{tabular}




\section{DISCUSSION}

The study shows that when students talk about their positive experiences of the Medicine Hunt, their focus is to a large extent on authentic science, and covers many of the aspects the Medicine Hunt aimed to introduce in school, like the hands-on and inquiry-based ways of working and the opportunity to do what scientists do. Students' answers are also to a high degree connected to the science content and to learning science. Together, these show that students' appreciation for the project emerges from science. Only a few students talk about the general excitement of being part of something exclusive or taking part in a competition. The results are relatively stable across the three classes.

The main result from this study is that students' experiences from the STSP were positive and related to science. This result extends previous findings from STSPs (e.g. Fougere, 1998; Houseal, AbdEl-Khalick \& Destefano, 2014; Means, 1998; Sadler, Burgin, McKinney \& Ponjuan, 2010; Wurstner, Herr, Andrews \& Alley, 2005) as it highlights which parts of the learning context students refer their experiences to-that the experiences relate to science through the hands-on and inquiry-based activities, the opportunities to do things scientists do and the questions linked to everyday life. At the same time, the results add to evidence of students' positive affective experiences of partnerships with researchers. Earlier studies have for example shown that students feel pride and usefulness when they collaborate with researchers and work with real issues (Means, 1998) and that these projects can lead to increased excitement and interest for science (e.g. Fougere, 1998; Wurstner, Herr, Andrews \& Alley, 2005). Students in the Medicine Hunt made statements in line with these earlier findings through comments such as

we get engaged in something only grown-ups do, and when children can help, and see how they and

work, and join in, and continue on our own

one gets more interested in science when one can do something like this.

The positive experiences students reported are also in line with factors shown as motivating in science contexts other than collaborations with researchers. Examples of such factors are hands-on and inquiry-based work and meaningful learning where science could be linked to reality (Bryan, Glynn \& Kittleson, 2011; Potvin \& Hasni, 2014; Velayutham \& Aldrige, 2013). Of particular note is that the Medicine Hunt, designed to include a broad group of both motivated and less motivated students, generated positive experiences from almost all students. For example, one student with low motivation for science thought that

it [the science task] was fun, but it did smell bad. It was different to what we normally do in science lessons

and

it felt special, to help the scientists feels good for the future [...] it was different to what we would have done otherwise, we have done a lot by ourselves.

Most previous studies of students collaborating with scientists have focused on groups where students volunteer to participate based on interest and skills in science which may give a skewed picture of the outcomes of such projects (see Sadler, Burgin, McKinney \& Ponjuan, 2010). The outcome of the Medicine Hunt, however, indicates that STSPs have potential to motivate students who are less keen on the traditional way science is often taught by providing something different with a greater focus on knowledge production and inquiry, in line with progressive school science (Zacharia \& Calabrese Barton, 2004).

Other results that warrant further investigation are the roles of continuity in teaching and the importance of doing things in ways different to the usual, and thereby increase variation in science teaching. Both those factors were reoccurring in interview answers from students in the Medicine Hunt and, to my knowledge, the importance of them are not investigated and documented in earlier research literature. They are of particular interest since they can easily be incorporated in science teaching without arranging collaborations with scientists. However, how this best can be done remains to be evaluated. 
When interpreting the findings it is important to remember that the number of students in the study was limited, even if they represent three different classroom contexts. Also, only one STSP was included in the study. A more extensive study could have brought in a wider range of experiences and perhaps generated clearer results. Further, as with all interviewing, there was a number of issues, not least was that some of the teenage students were not used to, or did not feel comfortable, putting words to their experiences, or simply had not thought much about science education before the interviews. Running semi-structured group interviews could have resulted in more dynamic data as the students could have supported each other's reflections. A downside to such an approach, that individual interviews overcome, it that the students would influence each other and one self-assured individual could direct the line of reflection.

In sum, this study shows that students value many core aspects of the authentic science experience. They value the way scientists work when conducting research, and the science content, per se. This finding has direct implications for setting up an STSP or similar forms of collaboration project that aim to introduce aspects of authentic science to students. Usefully, many of the features the students appreciated with the authentic experience, for example work with real-world problems, hands-on and inquiry-based methods, continuity and variation are possible to implement without participating in STSP such as The Medicine Hunt.

Providing more resources for working with inquiry-based and hands on science in schools will contribute to students being less likely to experience science as difficult, decontextualized and taught with transmissive pedagogy in the way described by Lyons (2006). Moreover, in the Swedish context, it will specifically support teachers in their work guiding students towards achieving the goals outlined in Swedish National curriculum (The Swedish National Agency for Education, 2011). Teacher education programmes and professional development courses for in-service teachers have a key role in providing schools with the teaching skills and necessary resources for working effectively with inquiry-based and hands on science in ways that can be achieved in all secondary classrooms.

When establishing STSPs, Houseal, Abd-El-Khalick and Destefano (2014) argued that it is important that the relationship between scientists and teachers is not a short-term, one-off relationship, but rather that it is a long-term cooperation between the research scientists and the teachers. Long-term cooperation, I suggest, would support the development of within-curriculum programmes, would allow teachers to become more powerful actors in the implementation of collaborations with scientists and in developing school science towards a more authentic approach, and, perhaps most importantly, would mean that teachers can be more readily supported to implement STSPs flexibly in ways appropriate for their particular teaching and learning situation. Such flexibility makes it possible for teachers to reach, motivate, and support all students in their classes. It is therefore also advisable to create these within-curriculum programmes for everyone rather than as extra-curricular programmes exclusively for the most motivated and/or skilled students. This requires implementation flexibility and teachers are key resources with their intimate knowledge of their classes and contexts.

Some of those best suited to be our future scientists, engineers, journalists and politicians with responsibilities for important science-related issues in society may be among those for whom traditional school science does not appeal. Without the additional impetuous provided by an STSP, or other authentic science activities, these students may never experience science as anything more than a decontextualized, difficult school subject and not be motivated to investigate careers that involve science. For our future, we need to support ways that assure authentic aspects of science reach every school student.

\section{ACKNOWLEDGEMENTS}

This work was supported by the Swedish Research Council (Grant 2007-3216). We thank the Nobel Museum, Stockholm, for their help with establishing contact with teachers and students participating in the student-teacher-scientist partnership "The Medicine Hunt”. 


\section{REFERENCES}

Braund, M., \& Reiss, M. (2006). Towards a more authentic science curriculum: the contribution of out-of-school learning. International Journal of Science Education, 28(12), 1373-1388. doi: 10.1080/09500690500498419

Bryan, R. R., Glynn, S. M., \& Kittleson, J. M. (2011). Motivation, achievement, and advanced placement intent of high school students learning science. Science Education, 95(6), 1049-1065. doi: $10.1002 /$ sce.20462

Fougere, M. (1998). The Educational Benefits to Middle School Students Participating in a Student/ Scientist Project. Journal of Science Education and Technology, 7(1), 25-30.

Hellgren, J. M., \& Lindberg, S. (2017). Motivating Students with Authentic Science Experiences: Changes in motivation for school science. Research in science and technological education, 35(4), 409-426. doi: 10.1080/02635143.2017.1322572

Houseal, A. K., Abd-El-Khalick, F., and Destefano, L. (2014). Impact of a Student-Teacher-Scientist Partnership on Students' and Teachers' Content Knowledge, Attitudes toward Science, and Pedagogical Practices. Journal of Research in Science Teaching, 51(1), 84-115. doi: 10.1002/ tea.21126

Lave, J., \& Wenger, E. (1991). Situated learning. Legitimate peripheral participation. Cambridge: University of Cambridge Press.

Lawless, J. G. \& Rock, B. N. (1998). Student Scientist Partnerships and Data Quality. Journal of Science Education and Technology, 7(1), 5-13.

Lyons, T. (2006). Different Countries, Same Science Classes: Students' experiences of school science in their own words. International Journal of Science Education, 28(6), 591-613. doi: 10.1080/09500690500339621

Mc Donald, J. H. (2009). Handbook of biological statistics. Baltimore, Maryland: Sparky House Publishing.

Means, B. (1998). Melding Authentic Science, Technology, and Inquiry-Based Teaching: Experiences of the GLOBE Program. Journal of Science Education and Technology, 7(1), 97-105.

Moss, D. M., Abrams, E. D., \& Kull, J. A. (1998). Can we be scientists too? Secondary students' perceptions of scientific research from a project-based classroom. Journal of Science, Education, and Technology, $7(2), 140-161$.

Neuendorf, K. A (2001). The Content Analysis Guidebook. Thousand Oaks, California: SAGE Publications.

OECD, (2008). Encouraging Student Interest in Science and Technology Studies (Policy Report). Paris: OECD Global Science Forum.

https://www.bvekennis.nl/Bibliotheek/o9-0070_OECD_science.pdf

Accessed 26 October 2018

Osborne, J., \& Dillon, J. (2008). Science education in Europe: Critical reflections (A report to the Nuffield Foundation). http://www.nuffieldfoundation.org/sites/default/files/Sci_Ed_in_Europe_Report_Final.pdfAccessed 21 April 2017.

Potvin, P., \& Hasni, A. (2014). Interest, motivation and attitude towards science and technology at K-12 levels: a systematic review of 12 years of educational research. Studies in Science Education, 5O(1), 85-129. doi: 10.1080/03057267.2014.881626

Ryan, R. M., \& Deci, E. L. (2000). Self-determination theory and the facilitation of intrinsic motivation, social development, and well-being. American psychologist, 55(1), 68-78. doi: 10.1037/0003-066X.55.1.68

Sadler, T. D., Burgin, S., McKinney, L., \& Ponjuan, L. (2010). Learning science through research apprenticeships: A critical review of the literature. Journal of Research in Science Teaching, 47(3), 235-256. doi: 10.1002/tea.20326

Sjøberg, S., \& Schreiner, C. (2010). The ROSE project. An overview and key findings. http:// roseproject.no/network/countries/norway/eng/nor-Sjoberg-Schreiner-overview-2010.pdf Accessed 21 April 2017. 
The Swedish National Agency for Education (Skolverket). (2011). Curriculum for the compulsory school, preschool class and the recreation centre, (SKOLFS 2010:37). http://www.skolverket. se/publikationer?id=2687 Accessed 21 September 2015.

Velayutham, S., \& Aldridge, J. M. (2013). Influence of psychosocial classroom environment on students' motivation and self-regulation in science learning: A structural equation modelling approach. Research In Science Education, 43(2), 507-527. doi: 10.1007/s11165-011-9273-y

Wormstead, S. J., Becker, M. L. \& Congalton, R. G. (2002). Tools for Successful Student-TeacherScientist Partnerships. Journal of Science Education and Technology 11(3), 277-287. doi: 10.1023/A:1016076603759

Wurstner, S., Herr, C., Andrews, G., \& Alley, K. (2005). Teacher/Scientist Partnership Develops a Simulated Natural Disaster Scenario to Enhance Student Learning. Journal of Geoscience Education, 53(5), 522-530.

Zacharia, Z., \& Calabrese Barton, A. (2004). Urban middle-school students' attitudes toward a defined science. Science Education 88(2), 197-222. doi: 10.1002/sce.10110 